\title{
SŁAWOMIR GODEK
}

\author{
Uniwersytet Kardynała Stefana Wyszyńskiego
}

\section{PIERWIASTKI ROMANISTYCZNE W PRAWIE SPADKOWYM I STATUTU LITEWSKIEGO}

Wiek XVI przyniósł Europie wyraźne ożywienie prądów kodyfikacyjnych $^{1}$. Ze szczególną intensywnością ujawniły się one w Wielkim Księstwie Litewskim. Już wcześniej - w XV stuleciu - Litwa przeżywała okres pewnej aktywizacji działalności prawodawczej. Był on związany $z$ powolnym procesem przechodzenia od prawa zwyczajowego do pisanego ${ }^{2}$. Stopniowe rozszerzanie sfery prawa pisanego oraz próby jego systematyzacji doprowadziły do wydania w roku 1468 Sudiebnika Kazimierza Jagiellończyka³. Jednak dopie-

${ }^{1}$ Por. S. Salmonowicz, Narodziny nowożytnej myśli kodyfikacyjnej w Europie, «CPH» 29.1 (1977), s. 77-104; W. URUSZCZAK, Europejskie kodeksy prawa doby renesansu, «CPH» 40.1 (1988), s. 59-90.

${ }^{2}$ Por. S. F. SoKoŁ, Politiczeskaja i prawowaja mysl $w$ Biełorussi $X V I$ - pierwoj potowiny XVII w., pod red. I.A. JuCHO, Mińsk 1984, s. 25 i n.

${ }^{3}$ Por. I.I. ŁAPPO, „Sudiebnik” Kazimira Jagajtowicza, «Zapiski Russkago Naucznogo Instituta w Belgradie», wypusk 17, Belgrad 1939, s. 23-36 (osobna odbitka); I.P. Starostina, Iz istorii razyskanija spiskow Sudiebnika Kazimira 1468 g., «Driewniejszije Gosudarstwa na Territorii SSSR» (1975), s. 180-195; TEJżE, O miestie Sudiebnika Kazimira 1468 g. w prawie Wielikogo Knjażestwa Litowskogo, [w:] Kulturnyje swjazi narodow Wostocznoj Jewropy w XVI w. pod red. B.A. RYBAKOWA, Moskwa 1976, s. 94 i n.; TEJŻE, Niekatoryje osobennosti razwitja prawa wostocznostawianskich zemel w Wielikom knjażestwie Litowskom, [w:] Rossija, Polsza i Priczernomorje w XV-XVIII $w w$, pod red. B.A. RyBaKowa, Moskwa 1979, s. 118-134; TejżE, Sudiebnik Kazimira 1468 g. , «Driewniejszije Gosudarstwa na Territorii SSSR» (1988-89), s. 170 i n., 336 
ro z chwilą wydania I Statutu litewskiego w roku $1529^{4}$ proces kodyfikacji prawa Wielkiego Księstwa zyskał znacznie na intensywności i począł wchodzić w fazę decydującą, która zaowocowała wydaniem dalszych dwóch Statutów z lat 1566 i 1588.

Tymczasem kodyfikacyjny debiut Litwinów wypadł nadspodziewanie dobrze. Liczący 13 rozdziałów i 282 artykuły I Statut stanowił kodyfikację udaną, na ogół pozytywnie ocenianą przez badaczy prawa litewskiegos . Osiągnięcie litewskiej kultury prawniczej było

i n.; V. ANDRIULIS, Osnownyje czerty ugotownogo prawa $i$ ugotownogo processa $w$ Litwie XV w. (Sudiebnik Kazimira), [w:] Teisés bruožai Lietuvoje XV-XIX a., pod red. V. ANDRIULISA, Wilno 1980, s. 6-23.

${ }^{4}$ Por. S. KuTRzeBA, Historia ustroju Polski w zarysie, II: Litwa, Lwów, Warszawa 1921, s. 121 i n.; TENŻE, Historia źródet dawnego prawa polskiego, II, Lwów, Warszawa-Kraków, bez daty, s. 69 i n.; I. JonYNAs, Pirmasis Lietuvos Statutas. 400 mety sukaktuviu proga, Kowno 1930, ss. 15 [osobna odbitka z «Vairas» 2 (1930)]; K.I. JABLONSKIS, Statut Wielikogo Knjażestwa Litowskogo 1529 g., Mińsk 1960, s. 3-12; S. ŁAZUTKA, I Litowskij Statut - fieodalnyj kodeks Wielikogo Knjażestwa Litowskogo, Wilno 1973, s. 58 i n.; TENŻE, Lietuvos statutai 1529, 1566, 1588, Kowno 1994, ss. 47; J. BARDACH, O I Statucie litewskim, «CPH» 28.2 (1976), s. 239-247; TENŻE, $Z$ najnowszych badań nad historia prawa litewskiego, «CPH» 32. 2 (1980), s. 203-207; TENŻE, Statuty litewskie w ich kręgu prawno-kulturowym, [w:] O dawnej i niedawnej Litwie, Poznań 1988, s. 17 i n.; TENŻE, Statuty litewskie a prawo rzymskie, Warszawa 1999, s. 14 i n. Por. też Pierwyj litowskij statut 1529 goda. Materiaty respublikanskoj naucznoj konfieriencji, poswiaszczennoj 450-letju Pierwogo Statuta, Wilno 1982, ss. 155.

${ }^{5}$ Por. J. JAKUBOwSKI, Studia nad stosunkami narodowościowymi na Litwie przed Uniq Lubelska, Warszawa 1912, s. 72 i n.; J. LELEwel, Dzieje Litwy i Rusi aż do Unii z Polska w Lublinie 1569 zawartej, Warszawa 1969, s. 159; I. P. STARostinA, K woprosu ob ewolucji prawa Wielikogo Kniażestwa Litowskogo w konce XV-naczale XVI wieka (na primere sopostawlienia Kazimira 1468 g. i I Litowskogo Statuta), [w:] Pierwyj litowskij statut 1529 goda, cit., s. 119-129; TEJŻE, Sudiebnik Kazimira 1468 g. , cit., s. 322 i n.; J. OcHmański, Historia Litwy, Wrocław-Warszawa-Kraków 1990, s. 106. Wśród badaczy, którzy zajmowali wobec Statutu bardziej powściągliwe stanowisko, uważając go za ledwie zwód prawa, a nie kodyfikację, wymienić można przykładowo S. EstreICHERA, Kultura prawnicza w Polsce XVI wieku, [w:] Kultura staropolska, Kraków 1932, s. 72 i n.; S. ŁAZUTKE, I Litowskij Statut, cit., s. 147 i n.; I.A. Jucho, Prawowoje potożenije nasielienija Bietorussi w XVI w., Mińsk 1978, s. 58; TENŻE, Krynicy biełaruska-litoūskaga prawa, Mińsk 1991, s. 76; TENŻE, Karotki narys gistorii djarżawy i prawa Biełarusi, Mińsk 1992, s. 164. 
tym większe, że w toku prac kodyfikacyjnych z powodzeniem rozwiązano bardzo wiele skomplikowanych kwestii teoretycznych i praktycznych $w$ trudnych warunkach braku wcześniejszych doświadczeń tak własnych, jak i obcych. Twórcy I Statutu musieli zmierzyć się z problemem rozgraniczenia norm prawnych i religijnych, określeniem zasad klasyfikacji przepisów, przyjęciem wewnętrznej struktury i systemu kodyfikacji, a wreszcie $z$ analizą i wyborem odpowiednich norm prawa zwyczajowego, które w wielkiej liczbie i różnorakich odmianach obowiązywały w poszczególnych częściach kraju. Osobnym, a równie doniosłym zadaniem, było przystosowanie starych norm do nowej i coraz szybciej zmieniającej się sytuacji wewnętrznej. W związku z tym kwestią pierwszorzędnego znaczenia było również umiejętne wykorzystanie obszernego i bardzo różnorodnego materiału prawnego, który pozostawał w dyspozycji kodyfikatorów. Proces ten wymagał znacznego wysiłku i dużej wiedzy, znajomości praktyki prawnej oraz wykorzystania zdobyczy nauki, a w szczególności zastosowania osiągnięć prawa rzymskiego ${ }^{6}$. Ostatecznie autorzy Statutu zużytkowali zarówno prawo zwyczajowe - litewskie i ruskie - jak i prawo pisane. Z masy tego ostatniego wykorzystali Sudiebnik Kazimierza Jagiellończyka, Ruskg Prawde, przywileje ziemskie, przepisy prawa polskiego, mazowieckiego, niemieckiego, czeskiego, rzymskiego oraz kościelnego, a w jego ramach zarówno ustawodawstwo Kościoła katolickiego, jak i prawosławnego?.

\footnotetext{
${ }^{6}$ Por. S. F. SoKoŁ, Politiczeskaja i prawowaja mysl w Bietorussi, cit., s. 27 i n.

${ }^{7}$ Por. T. CzAcKI, O litewskich i polskich prawach o ich duchu, źródtach, zwiazku, i o rzeczach zawartych $w$ pierwszym Statucie dla Litwy 1529 roku wydanym, wyd. K.J. TurowsKI, I, Kraków 1861, s. 53; F.I. LEONTOwICZ, Spornyje woprosy po istorii russko-litowskago prawa, Petersburg 1893, s. 4 i n.; TENŻE, Istoczniki russko-litowskogo prawa, Warszawa 1894, s. 5 i n.; N. MAKSIMIEJKO, Istoczniki ugotownych zakonow litowskogo statuta, Kijów 1894, ss. 189; O. BALzer, Prof. Piekosiński i Statuty litewskie, [w:] Przygodne stowa, Lwów 1912, s. 189 i n.; J. JAKUBOwsKI, Studia, cit., s. 72 i n.; R. ŁASZCZENKO, Litowskij Statut, jako pamjatnik ukrainskogo prawa, [s.d. s.l.], s. 19 i n.; S. Ehrenkreutz, Stan badań nad Statutami litewskimi, «Ateneum Wileńskie» 2 (1924), s. 322 i n.; TENŻE, Zagadnienie wptywu prawa rzymskiego na
} 
Zakres oraz sposób wykorzystania wszystkich wymienionych źródeł nie został jeszcze w pełni wyjaśniony. Dotyczy to w szczególności prawa rzymskiego. Być może, że stan ten jest po części - pomijając fragmentaryczność badań w tym kierunku - wynikiem żywotności poglądów głoszonych przez niektórych autorów w dawniejszej literaturze przedmiotu, że I Statut litewski, twór jeszcze nie w pełni dojrzały, tkwiący głęboko w sferze prawa feudalnego, opierający się w dużej mierze na zwyczaju, nie był jeszcze w stanie zaczerpnąć wzorców ze świetnie rozwiniętego prawa rzymskiego ${ }^{8}$. Z przedstawioną opinią harmonizował późniejszy pogląd, że to dopiero II Statut okazał się zdolnym - za sprawą uczonych romanistów - do przyswojenia elementów prawa rzymskiego?.

statuty litewskie, [w:] Pamiętnik VI Powszechnego Zjazdu Historyków Polskich w Wilnie 17-20 września 1935, I: Referaty, Lwów 1935, s. 189-196; W. HEJNosz, Statuty litewskie a prawo polskie, [w:] Pamiętnik, cit., s. 197-203; A. MikalausKas, Das Strafrecht der drei litauischen Statute von 1529, 1566, 1588, Kowno 1937, s. 61 i n.; W.I. PicZETA, Litowskij statut 1529 g. i jego istoczniki, [w:] Bietorussia i Litwa XV-XVI ww. (issliedowanija po istorii socjalno-ekonomiczeskogo, politiczeskogo i kulturnogo razwitja), Moskwa 1961, s. 503-521; K. vON LoEwE, The Lithuanian Statut of 1529, Lejda 1976, s. 2 i n.; I.A. JuCHO, Prawowoje potożenije nasielienija Bietorussi, cit., s. 57 i n.; S.F. SoKOŁ, Politiczeskaja i prawowaja mysl w Bietorussi, cit., s. 27; J. BARDACH, Statuty litewskie w ich kręgu prawno-kulturowym, cit., s. 26 i n.; TENŻE, Statuty litewskie a prawo rzymskie, cit., s. 23 i n.

${ }^{8}$ Por. T. CzACKI, Czy prawo rzymskie byto zasada praw litewskich i polskich? I czy $z$ pótnocnymi narodami mieliśmy wiele wspólnych praw $i$ zwyczajów?, Wilno 1809, s. 84 i n.; TENŻE, O litewskich i polskich prawach, I, cit., s. 53; A. MICKIEWICZ, Jaki wplyw prawodawstwo rzymskie na prawodawstwo polskie i litewskie mieć mogto?, «Dziennik Warszawski» 2.6 (1825), s. 140 i n. Por. też S. GodEK, Spór o znaczenie prawa rzymskiego w dawnej Rzeczypospolitej, «CPH» 54.1 (2002), s. 114.

${ }^{9}$ Por. I. DANIŁowICZ, Rzut oka historyczny na prawodawstwo litewskie, «Pamiętnik Naukowy» 1.2 (1837), s. 239, 254 i n., 261 i n.; I.I. ŁAPPO, Litowskij Statut 1588 goda, I. 1: Izsliedowanije, Kowno 1934, s. 93 i n, 96 i n., 101 i n.; TENŻE, Litowskij Statut 1588 goda, I. 2: Izsliedowanije, Kowno 1936, s. 78; R. TAUBENSCHLAG, Wplywy rzymsko-bizantyńskie w drugim Statucie litewskim, Lwów 1933, s. 36. O wpływie prawa rzymskiego na II Statut litewski por. też J. BARDACH, Uczone prawo w II Statucie Litewskim, [w:] 1566 Metu Antrasis Lietuvos Statutas, pod red. S. ŁAZUTKI, Wilno 1993, s. 15-23; TENŻE, Geneza romanizacji II Statu- 
Spróbujmy w części przynajmniej zweryfikować wspomniane poglądy i pokusić się jednak o odszukanie śladów oddziaływania prawa rzymskiego na I Statut. W tym celu skoncentrujmy uwagę na tej części litewskiej kodyfikacji, która dotyczy prawa spadkowego, a w szczególności dziedziczenia testamentowego.

Rozważania nad tym problemem wypada zacząć od konstatacji, że zasada swobody testowania w prawie litewskim pojawiła się w wyniku długotrwałych przemian stosunków politycznych i społeczno-ekonomicznych i w rozwiniętej formie nie znała jej jeszcze kodyfikacja z 1529 r. Ewolucję tę niegdyś scharakteryzował syntetycznie Przemysław Dąbkowski ${ }^{10}$, który pisał: „Statut I litewski dozwalał rozporządzać testamentem jedną trzecią częścią dóbr, ojczystych lub macierzystych, na rzecz kościoła lub obcych. Statut II zmienił to postanowienie o tyle, że dozwolił rozporządzać testamentem dobrami nabytymi, także na rzecz kościoła, a statut trzeci wyłączył wyraźnie spod dyspozycji testamentowej dobra ojczyste i macierzyste ..."11. Stan ten zatem róż-

tu litewskiego, [w:] Dawne prawo i myśl prawnicza. Prace historyczno-prawne poswięcone pamięci Wojciecha Marii Bartla, pod red. J. MALCA i W. URUSZCZAKA, Kraków 1995, s. 191-206; TENŻE, Wplyw prawa rzymskiego na Statuty litewskie oraz ich oddzialywanie na kraje sqsiednie, «Lithuania» 1-2 (1997), s. 12-25; S. GodeK, Prawo rzymskie w dawnej Rzeczypospolitej. Przeglad stanu badań, «CPH» 53.2 (2001), s. 48 i n.

${ }^{10}$ Por. P. DAвkKowski, Prawo prywatne polskie, II, Lwów 1911, s. 74; TENŻE, Dobra rodowe i nabyte w prawie litewskim od XIV do XVI wieku, Lwów 1916, s. 10 i n.

"Por. Statut I, V, 15: Koli by chto na reczi swoi ruchomyje abo na imenje, na kuplju, chotet tastament wcziniti, togdy takowyj, chotja by tez ne mocon byt, koli by tolko byt pri dobroj pamjati, mocon budet reczi swoi, imenje kuplenoje takowoje otkazywati kudy choczet, tak duchownym parsunam, jako i swetskim, prizwawszi k tomu kaptani abo inyje swetki, abo ljudi, wery godnyje, abo też jawnogo pisara prisjażnogo. A koli sam potom umret a tuju wolju swoju ostatocznuju smertju potwerdit, a chto by i peczati ne pritozit, takowyj tastament majet pri mocy zostati. A pak li by chto po wczineni tastamentu $i$ żiw zostat, wolno budet kożdomu kożdyj tastament swoj kolko krot choczet, tolko krot otmenit. A ostatocznym s tych wsich tastamentow smertju potwerżonyj, wradowne wczinenyj kożdomu wradom, majet pri mocy zostati. A imenje - kuplju tastamentom, jako i ruchomuju recz, kożdyj 
nił się znacząco od sytuacji obserwowanej w prawie rzymskim, w którym zasada wolności testowania bardzo wcześnie znalazła się wśród fundamentalnych reguł prawa i została wyrażona już w ustawie XII tablic ${ }^{12}$.

Po tym ogólnym spostrzeżeniu przejdźmy do szczegółowej analizy przepisów I Statutu. W pierwszej kolejności uwagę przykuwa interesujący zapis artykułu zatytułowanego Chto majet moc i ne majet o reczach swoich ruchomych testamenty cziniti.

Statut I, V, 14: Te $\dot{z}$ ustawljajem, iz kożdaja parsuna ne wolna $i$ ne mocna budet o reczach swoich tastament wcziniti, okrom tych parsun, niżej pisanych, kotoryje parsuny, pro to $\dot{z}$, iz podle prawa ne majut niczogo swojego wolnogo tastamentom nikomu otdati ${ }^{13}$.

możet otdaliti i prodati, komu choczet tak. Niżli chto by chotet kuplju na cerkow zapisati, tym obyczajem: kotoryjekolwe duchownyje toje imenje budet derzati, tolko majet s togo imenja stużbu zemskuju konno a zbrojno stuziti, wodle ustawy i ufaty zemskoje. Wżo ot togo czasu ustawujem, iz chto by zapisat imenje na kostet, togdy $s$ togo imenja także majet stużba byti, jako i perwej byta. A jesli by chto pered wradom abo pered swetkami, wery godnymi, otpisat tretjuju czast zapisom imenja abo kuplju, abo kotoruju ruchomuju recz, a chotja byt ziw, togdy wżo takowyj zapis majet derżan weczne byti; a onyj wżo drugij raz otozwati ani komu inszomu onoje reczi zapisywati a po wtoryj raz ne możet. Statut I cytuję w wersji ruskiej, a także polskiej i łacińskiej według wydania Pierwyj Litowskij Statut. Teksty na starobietorusskom, latinskom i staropolskom jazykach, II. 1, Wilno 1991. Por. Statut III, VIII, 1; VIII, 2; VIII, 9. III Statut litewski cytuję według wydania I.I. ŁAPPO, Litowskij Statut 1588 goda, II: Tekst, Kowno 1938. Por. Statut II, VIII, 1. II Statut litewski cytuję według Statut Wielikogo Knjazstwa Litowskogo 1566 goda, «Wriemiennik Imperatorskago Moskowskago Obszczestwa Istorii i Drewnostiej Rossijskich» 23 (1855).

${ }_{12}$ Tab. 5,3: Uti legassit super pecunia tutelave suae rei, ita ius esto. Por. też M. i J. ZabŁOCCY, Ustawa XII Tablic. Tekst - ttumaczenie - objaśnienia ${ }^{2}$, Warszawa 2003, s. 30 i n.; W. WoŁodKIEWICZ - M. ZABŁoCKA, Prawo rzymskie. Instytucje ${ }^{3}$, Warszawa 2001, s. 171.

${ }^{13}$ Por. też T. CZACKI, O litewskich i polskich prawach o ich duchu, źródtach, zwiazku, i o rzeczach zawartych w pierwszym Statucie dla Litwy 1529 roku wydanym, wyd. K.J. TURowsKI, II, Kraków 1861, s. 65 i n. 
Lektura cytowanego powyżej fragmentu sprawia wrażenie, że przepis zredagowany jest nieprecyzyjnie ${ }^{14}$. Pomimo to myśl ustawodawcy wydaje się być całkowicie czytelną. Prawodawca proklamuje wolność sporządzania testamentó $w^{15}$, ale $\mathrm{z}$ wyłączeniem pewnych ściśle określonych kategorii osób, którym tego prawa odmawia ${ }^{16}$. Konstrukcja tej prostej zasady oraz sposób jej wyrażenia koresponduje $\mathrm{z}$ fragmentem justyniańskich Instytucji.

\section{2,12 pr.: Non tamen omnibus licet facere testamentum. statim enim hi, qui alieno iuri subiecti sunt, testamenti faciendi ius non habent, adeo quidem ut, quamvis parentes eis permiserint, nihilo magis iure testari possint ${ }^{17}$...}

Z tekstu Instytucji wynika, że nie wszyscy mogą sporządzać testamenty. Prawa tego pozbawieni są ci, którzy podlegają władzy zwierzchników familijnych. Tak wyrażona zasada nie zna wyjątku nawet wówczas, gdy zwierzchnik familijny udzieliłby zezwolenia na sporządzenie testamentu osobie pozostającej pod jego władzą.

Podobieństwo między cytowanymi fragmentami polega na tym, iż osoby, o których źródła rzymskie mówiły jako o podległych czyjejś władzy (qui alieno iuri subiecti sunt), Statut określa jako te, które podle prawa ne majut niczogo swojego wolnogo. Zamiana ta - jak się wydaje - ma w tym miejscu swoje realne uzasadnienie. Zabieg

${ }^{14}$ Wątpliwości budzi sformułowanie kożdaja parsuna ne wolna i ne mocna budet o reczach swoich tastament wcziniti, które nie przystaje do dalszej części wypowiedzi. Wydaje się, iż znacznie poprawniej skonstruowany jest odnośny artykuł w tłumaczeniu polskim i łacińskim - Statut I, V, 17: Tesz ustavuiem, isz koszda persona i moczna będzie o rzeczach swoich testament czinicz, okrom tich person, niżej napisanich, ktore personi przeto i podle prawa ni maiq niczego swoiego volnego testamentem nikomu oddacz. Statut I, V, 15: Testamentum super rebus suis condere licet vnicuique preter personas infrascriptas, que quoniam secundum ius nichil suum proprium habent, ideo non possunt legare.

${ }^{15} \mathrm{~W}$ granicach i na zasadach określonych w Statucie I, V, 15.

${ }^{16}$ Zupełnie jasno wyrażały już tę zasadę Statut II, VIII, 1 oraz Statut III, VIII, 1.

${ }^{17}$ Por. też D. 28,1,6 pr.: Qui in potestate parentis est, testamenti faciendi ius non habet. Adeo ut, quamvis pater ei permittat, nihilo magis tamen iure testari possit. 
ten pozwolił ustawodawcy litewskiemu na uzasadnienie pozbawienia pewnych kategorii osób zdolności do sporządzania testamentów i wyjaśnienie przyczyn tego kroku w duchu prawa rzymskiego, a jednocześnie na uniknięcie powołania na antyczny model podległości władzy zwierzchnika familijnego, który w wieku XVI i w warunkach litewskich nie byłby dostatecznie czytelny.

Dalsza część omawianego artykułu statutowego zawiera już dokładne wyliczenie poszczególnych kategorii osób nie posiadających zdolności do czynienia testamentów. Statut z 1529 r. jako pierwsze wymienia dzieci.

Statut I, V, 14: Naperwej, deti, let zupotnych ne majuczi ${ }^{18}$...

W tym samym kontekście o niedojrzałych mówiły źródła rzymskie.

I. 2,12,1: Praeterea testamentum facere non possunt impuberes, quia nullum eorum animi iudicium est ${ }^{19}$...

Z powyższego porównania wynika, że nie tylko I Statut, ale także kolejne Statuty zgodne były w omawianym punkcie z prawem rzymskim. Jedyną różnicą, której w zestawionych normach można się doszukać, jest okoliczność, że prawo rzymskie podawało również przyczynę, dla której zdecydowało o pozbawieniu niedojrzałych prawa do sporządzania testamentów, natomiast uzasadnienia takiego nie zawierają normy statutowe ${ }^{20}$.

${ }^{18}$ Podobnie Statut II, VIII, 1 oraz Statut III, VIII, 1. Por. A. MickIEWICZ, op. cit., s. 144; P. DĄBKOWSKI, Prawo prywatne polskie, II, cit., s. 69 i n.

${ }^{19}$ Por. też Ulp. 20,12: Impubes, licet sui iuris sit, facere testamentum non potest, quoniam nondum plenum iudicium animi habet. G. 2,113: ... nam masculus minor annorum quattuordecim testamentum facere non potest, etiamsi tutore auctore testamentum facere velit ... Regulae Ulpiani oraz Instytucje Gaiusa nie były znane w dobie powstawania Statutów litewskich. Cytuję je jednak pomocniczo obok źródeł justyniańskich w celu pełniejszej ilustracji omawianych instytucji rzymskich. Por. też P. VocI, Diritto ereditario romano, I, Milano 1967, s. 390 i n.; P. BONFANTE, Istituzioni di diritto romano, Milano 1987, s. 474 i n.; W. WOŁODKIEWICZ - M. ZABŁOCKA, op. cit., s. 180.

${ }^{20} \mathrm{Na}$ podobieństwa zachodzące między przepisami rzymskimi i litewskimi w kwestii ograniczeń w możliwości sporządzania testamentów zwracali już nie- 
Drugą kategorią osób pozbawionych prawa do sporządzania testamentów i wymienioną przez kodyfikację z 1529 r. byli zakonnicy, przebywający w zakonie uprzywilejowanym.

Statut I, V, 14: ... zakonniki, buduczi w zakone priwilewanom, prinjawszi, potwerdiwszi sja $w$ zakone ${ }^{21}$...

W punkcie tym stwierdzamy różnicę między przepisami litewskimi i rzymskimi. Prawo rzymskie nie zakazywało mnichom spisywania aktów ostatniej woli.

C. 1,3,20: Si quis presbyter aut diaconus aut diaconissa aut subdiaconus vel cuiuslibet alterius loci clericus aut monachus aut mulier, quae solitariae vitae dedita est, nullo condito testamento decesserit nec ei parentes utriusque sexus vel liberi vel si qui agnationis cognationisve iure iunguntur vel uxor extiterit, bona, quae ad eum vel ad eam pertinuerint, sacrosanctae ecclesiae vel monasterio, cui fuerat destinatus aut destinata, omnifariam socientur...

Z przytoczonej konstytucji Teodozjusza i Walentyniana wynika, że prezbiterzy, diakoni, subdiakoni, mnisi oraz inne osoby duchowne, również płci żeńskiej, zdolne są do sporządzania testamentów. Zatem wykluczenie zakonników od tej czynności przez prawo litewskie nie było inspirowane wzorcami rzymskimi ${ }^{22}$. Należy przy

gdyś uwagę F. MORzE, O wptywie prawodawstwa rzymskiego na prawodawstwo polskie i litewskie, «Dziennik Warszawski» 5.14 (1826), s. 118 i n.; R. TAUBENSCHLAG, op. cit., s. 28 i n.; K. KORANYI, O niektórych postanowieniach karnych Statutu litewskiego z r. 1529 [w:] Księga pamiatkowa ku uczczeniu czterechsetnej rocznicy wydania pierwszego Statutu Litewskiego, pod red. S. EHRENKREUTZA, Wilno 1935, s. 124. Por. też J. BARDACH, Statuty litewskie a prawo rzymskie, cit., s. 146 i n.

${ }^{21}$ Por. też uwagi J. BARDACHA, Statuty litewskie a prawo rzymskie, cit., s. 146 o rozbieżnościach dotyczących zakazu testowania przez zakonników, tkwiących w tekstach II Statutu, a mianowicie w jego wersji ruskiej, polskiej i łacińskiej.

${ }^{22}$ Por. K. KoRANYI, O niektórych postanowieniach karnych Statutu litewskiego $z$ r. 1529 , cit., s. 124 i n. 
tym zauważyć, że w obu rozpatrywanych ustawodawstwach testamenti factio activa przysługiwała duchownym świeckim ${ }^{23}$.

W dalszej kolejności I Statut wymieniał synów niedzielnych z ojcem.

Statut I, V, 14: ... synowe, $z$ otcom nedelnym, okrom reczi nabytja swojego wtastnogo abo wystugu ${ }^{24}$...

Powyższy fragment znajduje odniesienie w tekstach justyniańskich Digestów i Instytucji.

D. 28,1,6 pr.: Qui in potestate parentis est, testamenti faciendi ius non habet, adeo ut, quamvis pater ei permittat, nihilo magis tamen iure testari possit.

I. 2,12 pr.: Non tamen omnibus licet facere testamentum. statim enim hi, qui alieno iuri subiecti sunt, testamenti faciendi ius non habent, adeo quidem ut, quamvis parentes eis permiserint, nihilo magis iure testari possint ${ }^{25} \ldots$

$\mathrm{Z}$ cytowanych fragmentów wynika, że prawo rzymskie w sposób bardzo kategoryczny zabraniało sporządzać testamenty osobom alieni iuris. Zakaz, o którym mowa, był na tyle rygorystyczny, że nie mogła go znieść nawet odmienna wola rodziców, zezwalających na sporządzenie testamentu własnym dzieciom.

Wydaje się, że przytoczone przepisy litewskie i rzymskie są identyczne pod względem celu i zasady. Wszak filius familias nie może testować, gdyż nie ma własnego majątku, a wszystko co ewentualnie nabywa, nabywa na swojego zwierzchnika familijnego. Podobny schemat obserwujemy w warunkach litewskich - nie ma nic własne-

${ }^{23}$ Por. P. DĄBKowsKi, Prawo prywatne polskie, II, cit., s. 70, 79 i n., 113; J. GERLACH, Stanowisko duchownych wedle statutu litewskiego III (1588 roku), «Ateneum Wileńskie» 1 (1923), s. 19; M. BoRKOWSKA, Dekret w niebieskim ferowany parlamencie. Wybór testamentów z XVII-XVIII wieku, Kraków 1984, s. 9.

${ }^{24}$ Bardzo podobnie Statut II, VIII, 1 oraz Statut III, VIII, 1.

${ }^{25}$ Por. też Ulp. 20,10: Filius familiae testamentum facere non potest, quoniam nihil suum habet, ut testari de eo possit. 
go syn, który jeszcze nie otrzymał od ojca wydzielonej, przypadającej na niego części majątku. Zwróćmy uwagę, że ustawodawca litewski formułując normę statutową, zamienił jedynie napotkaną w źródle justyniańskim rzymską instytucję władzy ojcowskiej na instytucję rodzimą w postaci niedziału ojca $\mathrm{z}$ synami. Rozwijając ten wątek skonstatujmy, że prawodawca litewski wykazał konsekwencję i wyjątki od przedstawionej wyżej reguły również sformułował w duchu prawa rzymskiego. Zezwolił mianowicie synom niedzielnym na testowanie rzeczami nabytja swojego wtastnogo abo wystugu. Identyczna i bardzo charakterystyczna zasada obowiązywała w prawie rzymskim. Została ona wyłożona w justyniańskich Instytucjach i Digestach.

I. 2,12 pr.: Non tamen omnibus licet facere testamentum. statim enim hi, qui alieno iuri subiecti sunt, testamenti faciendi ius non habent, adeo quidem ut, quamvis parentes eis permiserint, nihilo magis iure testari possint: exceptis his quos antea enumeravimus et praecipue militibus qui in potestate parentum sunt, quibus de eo quod in castris adquisierint permissum est ex constitutionibus principum testamentum facere. quod quidem initio tantum militantibus datum est tam ex auctoritate divi Augusti quam Nervae nec non optimi imperatoris Traiani, postea vero subscriptione divi Hadriani etiam dimissis militia, id est veteranis, concessum est. Itaque si quidem fecerint de castrensi peculio testamentum, pertinebit hoc ad eum quem heredem reliquerint ... praeter hos igitur, qui castrense peculium vel quasi castrense habent, si quis alius filius familias testamentum fecerit, inutile est ...

I. 2,10,9: ... sed si filius familias de castrensi peculio post missionem faciat testamentum ${ }^{26}$...

I. 2,11 pr.: ... sed testari quidem et si filii familias sunt propter militiam conceduntur...

\footnotetext{
${ }^{26}$ Por. też G. 2,106.
} 
I. 2,11,6: Sciendum tamen est, quod ad exemplum castrensis peculii tam anteriores leges quam principales constitutiones quibusdam quasi castrensia dederunt peculia, quorum quibusdam permissum erat etiam in potestate degentibus testari. quod nostra constitutio latius extendens permisit omnibus in his tantummodo peculiis testari quidem, sed iure commu$n i^{27} \ldots$

D. 49,17,11: Castrense peculium est, quod a parentibus vel cognatis in militia agenti donatum est vel quod ipse filius familias in militia adquisiit, quod, nisi militaret, adquisiturus non fuisset. nam quod erat et sine militia adquisiturus, id peculium eius castrense non est.

Z przytoczonych fragmentów wynika, że osoby poddane czyjemuś prawu nie mogą sporządzać testamentów. Mocą konstytucji cesarskich wyjątek uczyniono dla żołnierzy i weteranów, którym - pomimo ich podległości władzy zwierzchnika familijnego - pozwolono sporządzać testamenty. Przedmiotem tych aktów mógł być jednak tylko majątek uzyskany od rodziców, krewnych lub w inny sposób podczas odbywania służby wojskowej (peculium castrense). Uprawnienie to rozciągnięto następnie w prawie klasycznym na majątek zgromadzony w związku ze sprawowaniem funkcji państwowych (peculium quasi castrense) ${ }^{28}$. Pozbawienie możliwości sporządzania testamentu synów, pozostających w niedziale $\mathrm{z}$ ojcem, jest zatem drugim punktem, w którym prawo litewskie wykazuje zbieżność $\mathrm{z}$ prawem rzymskim w ramach omawianej problematyki.

${ }^{27}$ Por. też Ulp. 20,10: Filius familiae testamentum facere non potest, quoniam nihil suum habet, ut testari de eo possit. Sed divus Augustus [Marcus] constituit, ut filius familiae miles de eo peculio quod in castris adquisivit testamentum facere possit.

${ }^{28}$ Por. D. 49,17; C. 1,$3 ; 12,30 ; 12,36$. Por. też C. LoNGo, Corso di diritto romano. Diritto di famiglia, Milano 1946, 129 i n.; G. FRANCIOSI, Famiglia e persone in Roma antica dall' età arcaica al principato, Torino 1992, s. 199 i n.; W. WoŁODKIEWICZ M. ZABŁOCKA, op. cit., s. 107 i n., 180. 
Ustawa z 1529 r. pozbawiała również prawa do sporządzania testamentów niewolników ${ }^{29}$.

Statut I, V, 14:... w czużuju moc zostawleny, to jest tot, kogo by komu wydano zy jego statki ... newolniki ${ }^{30}$...

Od możliwości testowania wykluczały niewolników także postanowienia prawa rzymskiego.

C. 6,59,4: Servus successores habere non potest ${ }^{31}$.

W dalszej kolejności I Statut wspomina o chorych umysłowo.

Statut I, V, 14: ... szaleni, kaceri, newolniki, ot rozumu otcho$\operatorname{djaczi}^{32} \ldots$

I Statut, a także idący za jego przykładem Statut II, wymieniają szalonych następnie kacerzy, za nimi niewolników i dopiero dalej, na końcu - odchodzących od rozumu. Sformułowanie to sprawia wrażenie, że litewski ustawodawca rozróżniał dwie kategorie ludzi

${ }^{29} \mathrm{O}$ źródłach niewoli mówi Statut I, XI, 12. Por. też Statut I, XI, 6; XI, 7; XI, 10. Por. też W. HeJnosz, Kilka uwag o ,niewoli" w I Statucie Litewskim, [w:] Księga pamiatkowa, cit., s. 329-362.

${ }^{30}$ Podobnie Statut II, VIII, 1 oraz Statut III, VIII, 1. Statut II, XII, 13 znał trzy zasadnicze źródła niewoli: urodzenie, jeniectwo i niewolę za długi. Odpowiada to prawu rzymskiemu - I. 1,3,4. Por. też Statut II, XII, 7; XII, 11; XII, 13, a także P. DĄBKowsKI, Prawo prywatne polskie, I, cit., s. 114; R. TAUBENSCHLAG, op. cit., s. 18 i n.; J. BARDACH, Statuty litewskie a prawo rzymskie, cit., s. 132 i n. III Statut ograniczył niewolę wyłącznie do jeniectwa. Statut III, XII, 21; XIV, 36. Por. też P. DABBKOwsKI, Prawo prywatne polskie, I, cit., s. 112 i n.; J. BARDACH, Statuty litewskie w ich kreggu prawno-kulturowym, cit., s. 58 i n.; M. F. SPIRIDONow, Zakreposzczenije kriestianstwa Bietarussi (XV-XVI ww.), Mińsk 1993, s. 71 i n., 94 i n.; J. JURKIEwICZ, Kilka uwag o poddaństwie wtościan na Biatorusi w XVI w., «Przegląd Historyczny» 87.1 (1996), s. 95-105.

${ }^{31}$ Wyjątkiem od wskazanej reguły był servus publicus. Ulp. 20,16: Servus publicus populi Romani partis dimidiae testamenti faciendi habet ius. Por. też W. LrTEWSKI, s.v. Servus publicus (servus populi romani), [w:] Stownik encyklopedyczny prawa rzymskiego, Kraków 1998, s. 243.

${ }^{32}$ Prawie identycznie Statut II, VIII, 1. Por. też Statut III, VIII, 1; XI, 35. 
chorych na umyśle. Po pierwsze szalonych (szaleni, szalenyje), czyli zupełnie pozbawionych rozumu w związku z trwałą chorobą psychiczną, a w następstwie także stale pozbawionych prawa do rozporządzania swą ostatnią wolą oraz osoby, które tylko okresowo popadają w zamroczenie umysłowe (ot rozumu otchodjaczi, ot rozumu otchodjaczije), a w konsekwencji zdolne do czynienia testamentów, gdy - jak głosi dalej I Statut - $k$ sobe prijdut. Zanim wskażemy na istotne znaczenie powyższego rozróżnienia dla naszych dociekań, zwróćmy uwagę na następujące fragmenty justyniańskich Instytucji i Digestów.

I. 2,12,1: Praeterea testamentum facere non possunt ... furiosi, quia mente carent ... certe eo quod ante furorem fecerint testamento valente: nam neque testamenta recte facta neque aliud ullum negotium recte gestum postea furor interveniens peremit.

I. 2,18 pr.: ... sed hoc dicitur, non quasi vere furiosus sit, sed recte quidem fecit testamentum, non autem ex officio pietatis: nam si vere furiosus est, nullum est testamentum.

D. 28,1,17: In adversa corporis valetudine mente captus eo tempore testamentum facere non potest.

Przywołane fragmenty zgodnie odmawiają chorym umysłowo prawa do sporządzania testamentu ${ }^{33}$. Zależność regulacji litewskich od unormowań rzymskich w rozpatrywanym punkcie stanie się bardziej wyrazista, gdy poddamy analizie dalszą część passusu statutowego, mówiącego o zdolności do testowania umysłowo chorych.

Statut I, V, 14: ... a wedżo tyje, koli $k$ sobe prijdut, mocny s tastamenty swoimi cziniti ${ }^{34}$.

${ }^{33}$ Wiąże się to zresztą z ogólną regułą zawartą w D. 50,17,5: ... furiosus nullum negotium contrahere potest... Por. też Ulp. 20,13: Mutus surdus furiosus itemque prodigus, cui lege bonis interdictum est, testamentum facere non possunt ... furiosus, quoniam mentem non habet ...

${ }^{34}$ Podobnie Statut II, VIII, 1 oraz Statut III, VIII, 1. 
Statut zatem pozwalał na sporządzenie testamentu tym spośród chorych na umyśle, którzy powrócą do zdrowia psychicznego ${ }^{35}$.

$\mathrm{Na}$ takim samym stanowisku stały normy rzymskie. W Instytucjach justyniańskich czytamy:

I. 2,12,1:... furiosi autem si per id tempus fecerint testamentum, quo furor eorum intermissus est, iure testati esse videtur ...

Ze wskazanego fragmentu wynika, że prawo rzymskie pozwalało choremu umysłowo na sporządzenie testamentu w momentach okresowego powrotu świadomości określanych jako lucida intervalla. Testament czyniony w czasie regresu choroby sporządzany był ważnie. W związku z tym nasuwa się wniosek, że I Statut, a za nim następne, respektowały tę charakterystyczną rzymską zasadę i konsekwentnie ją powtarzały.

I Statut litewski pozbawiał również prawa do sporządzania testamentów kacerzy. Wynika to z cytowanego już wcześniej fragmentu.

Statut I, V, 14: ... szaleni, kaceri, newolniki, ot rozumu otcho$\operatorname{djaczi}^{36} \ldots$

I Statut wymieniał kacerzy między - i na równi - $\mathrm{z}$ szalonymi oraz niewolnikami jako tych, którzy nie są zdolni do testowania. Stanowisko litewskiej kodyfikacji jest zbieżne z regulacjami rzymskimi.

${ }^{35}$ Por. też Statut I, V, 15; Statut II, VIII, 2; Statut III, VIII, 2. Składane przez testatora na kartach aktu ostatniej woli zapewnienie o tym, że czyni testament w warunkach całkowitego zdrowia psychicznego i przy dobrej pamięci, stanowi stały, bardzo charakterystyczny element testamentów litewskich z XVI, XVII i XVIII wieku. Por. Biržu dvaro teismo knygos 1620-1745, V. RAUDELIƠNAS - R. FIRKOVIČIUS, Wilno 1982, s. 228, 321; M. BorKOWSKA, op. cit., s. 32, 41, 52, 61, 67, 74, 101, 106, 109, 131, 134, 140, 153, 165, 174, 178, 189, 192; U. AugustyniaK, Testamenty ewangelików reformowanych $w$ Wielkim Księstwie Litewskim, Warszawa 1992, s. 17, 26, 34, 49, 62, 81, 123, 144, 169, 181, 185, 192, 199, 216, 237.

${ }^{36}$ Kacerzy wymieniał Statut II, VIII, 1. Brak tej kategorii w Statucie III. Por. T. CZACKI, O litewskich i polskich prawach, II, cit., s. 68, 70; R. TAUBENSCHLAG, op. cit., s. 29 i n.; I.I. ŁAPPO, Litowskij Statut 1588 goda, I. 2, cit., s. 435 i n.; J. BARDACH, Statuty litewskie w ich kregu prawno-kulturowym, cit., s. 44. 
C. 1,5,4,5: Ergo et suprema illius scriptura irrita sit, sive testamento sive codicillo sive epistula sive quolibet genere reliquerit voluntatem qui Manichaeus fuisse convincitur ...

Wskazany fragment Kodeksu justyniańskiego w sposób jasny, a zarazem bardzo dobitny precyzuje, że żadne pisemne rozporządzenie ostatniej woli dokonane przez zwolennika manicheizmu nie może być uznane za ważne. Przepis dotyczył zarówno testamentów, kodycyli, listów jak i innych form, w których wzmiankowana wola mogłaby być wyrażona.

W podsumowaniu należy stwierdzić, że uregulowania I Statutu litewskiego są zasadniczo zbieżne $\mathrm{z}$ rzymskimi w analizowanych elementach. Porównywane ustawodawstwa pozbawiały prawa do sporządzania testamentów niedojrzałych, niewolników, heretyków, synów pozostających pod władzą ojca oraz chorych umysłowo, przy czym w dwóch ostatnich przypadkach prawo litewskie recypowało rozwiązania rzymskie tak dalece, że uwzględniło je nawet w poszczególnych wyjątkach od zasad ogólnych ${ }^{37}$.

W poszukiwaniu kolejnych śladów oddziaływania urządzeń rzymskich na prawo litewskie warto zatrzymać się nad fragmentem I Statutu zawartym w dłuższym passusie poświęconym rygorom, jakim winna czynić zadość forma testamentu ${ }^{38}$.

\footnotetext{
${ }^{37}$ Instytucje justyniańskie wspominają łącznie o większości z wymienionych kategorii osób, jako o pozbawionych prawa do sporządzania testamentu. Por. I. 2,19,4: ... testamenti autem factionem non solum is habere videtur, qui testamentum facere potest, sed etiam qui ex alieno testamento vel ipse capere potest vel alii adquirere, licet non potest facere testamentum. Et ideo et furiosus et mutus et postumus et infans et filius familias et servus alienus testamenti factionem habere dicuntur: licet enim testamentum facere non possunt, attamen ex testamento vel sibi vel alii adquirere possunt. Por. też W. LITEWSKI, s.v. Testamenti factio activa, [w:] Stownik encyklopedyczny, cit., s. 256.

${ }^{38}$ Formy sporządzania testamentów w prawie litewskim i rzymskim wykazują w niektórych punktach podobieństwa. Por. A. MickIEwICZ, op. cit., s. 144; F. MoRZE, op. cit., s. 119. Statut III, VIII, 2 już dość dokładnie mówił o wymogu podpisania i opieczętowania testamentu przez testatora i świadków. Elementy te wymieniają również źródła rzymskie. Por. I. 2,10; Ulp. 23,6 oraz Statut I, V, 15; Statut II, VIII, 2; VIII, 3.
} 
Statut I, V, 15: A koli sam potom umret a tuju wolju swoju ostatocznuju smertju potwerdit, a chto by i peczati ne pritozit, takowyj tastament majet pri mocy zostati. A pak li by chto po wczineni tastamentu i żiw zostat, wolno budet kożdomu kożdyj tastament swoj kolko krot choczet, tolko krot otmenit. A ostatocznym s tych wsich tastamentow smertju potwerżonyj, wradowne wczinenyj kożdomu wradom, majet pri mocy zostati ${ }^{39}$.

$\mathrm{Z}$ powyższego przepisu wynika, że prawo statutowe gwarantowato testatorowi możliwość swobodnej zmiany testamentu. Za ostateczną uważano tę wersję testamentu, która spisana została jako ostatnia przed zgonem testatora i, o ile odpowiadała ona wymogom formalnym, miała pozostać w mocy (majet pri mocy zostati) ${ }^{40}$. Przedstawiony przepis statutowy jest - jak się wydaje - wiernym powtórzeniem rzymskiej zasady mówiącej o nieskrępowanej woli testatora aż do momentu śmierci.

D. 34,4,4: ... ambulatoria enim est voluntas defuncti usque ad vitae supremum exitum.

O możliwości swobodnej zmiany testamentu i poprzez ten fakt automatycznym uchyleniu postanowień poprzedniego aktu ostatniej woli wspominają także justyniańskie Instytucje.

I. 2,17,2: Posteriore quoque testamento, quod iure perfectum est, superius rumpitur ... nam et prius testamentum non valet ruptum a posteriore ${ }^{41} \ldots$

${ }^{39}$ Podobnie Statut II, VIII, 2; Statut III, VIII, 2. Siedemnastowieczna (i późniejsza) praktyka prawna świadczy o głębokim już zakorzenieniu omawianej zasady w warunkach litewskich. Por. M. BorkowsKA, op. cit., s. 74 i n.; U. AUGUSTYNIAK, op. cit., s. 169, 210; T. KEMPA, Mikotaj Krzysztof Radziwitt Sierotka (1549-1616), wojewoda wileński, Warszawa 2000, s. 317.

${ }^{40}$ Por. też A. MiCKIEWICZ, op. cit., s. 150 i n.; T. CZACKI, O litewskich i polskich prawach, II, cit., s. 71; P. DĄвKOwSKI, Prawo prywatne polskie, II, cit., s. 89 i n., 93 i n., 100.

${ }^{41}$ Identycznie G. 2,144. Por. też G. 2,151; 2,151a; I. 2,17,3; Ulp. 23,2: Rumpitur testamentum mutatione, id est si postea aliud testamentum iure factum sit. Por. też W. WoŁODKIEWICZ - M. ZABŁOCKA, op. cit., s. 181. 
Przeprowadzone powyżej porównanie dowodzi, że w rozpatrywanym elemencie zależność prawa litewskiego od rzymskiego datuje się już od czasu wprowadzenia w życie I Statutu i że trwała ona nieprzerwanie w okresie obowiązywania II i III Statutu.

Kolejnym artykułem I Statutu godnym rozpatrzenia pod kątem wpływów romanistycznych jest ten, noszący tytuł $O$ swetkoch, kotoryi majut byti pri spraweni tastamentow. Jego treść jest następująca:

Statut I, V, 16: Też ustawujem: pri tastamentach majut byti swet$k i$, wery godnyje a nepodozrenyje; pro to tyje swetki, niżej napisanyje swetki byti ne mogut: naperwej, tyje, kotoryje tastamentow swoich cziniti ne godny; też i newesty, ekzetutorowe abo opekunowe togo ż tastamentu; także też tyje, kotorym $w$ tom tastamente szto otpisano ${ }^{42}$.

Jak wynika $\mathrm{z}$ treści przedstawionego artykułu, I Statut wykluczał możliwość sprawowania funkcji świadka przy czynności sporządzania testamentu ${ }^{43}$ tych, którzy nie mieli prawa czynić testamentów: kobiety, egzekutorów testamentów oraz osoby nabywające coś $\mathrm{z}$ danego testamentu jako zapisobiorcy $\mathrm{y}^{44}$.

${ }^{42}$ Podobnie Statut II, VIII, 3; Statut III, VIII, 5. Por. też A. MicKIEWICZ, op. cit., s. 144; F. MoRZE, op. cit., s. 119; T. CZACKI, O litewskich i polskich prawach, II, cit., s. 72; P. DABKOWSKI, Prawo prywatne polskie, II, cit., s. 83, 89 i n.; R. TAUBENSCHLAG, op. cit., s. 30 i n.; J. BARDACH, Statuty litewskie a prawo rzymskie, cit., s. 148 i n.

${ }^{43} \mathrm{O}$ liczbie i kwalifikacjach świadków mówiły Statut I, V, 15; V, 16; Statut II, VIII, 2; VIII, 3; Statut III, VIII, 2. Por. też M. BorKowsKA, op. cit., s. 39, 45, 65, $83,86,99,104,108,111,121,128,133,137,150$ i n., 163, 172, 191, 205, 207; U. AUGUSTYNIAK, op. cit., s. 21, 45, 57, 75, 99, 117, 128, 164, 177, 185, 210 i n., 237. Nie sposób w tym miejscu nie wspomnieć o niezwykle interesującym przepisie II Statutu, który wymagał aż ośmiu świadków w wypadku, gdy testament sporządzała osoba niewidoma. Statut II, VIII, 8. Jest to całkowicie zbieżne $\mathrm{z}$ wymogami stawianymi przez prawo rzymskie. Por. C. 6,22,8; I. 2,12,4. Por. też R. TAUBENSCHLAG, op. cit., s. 35; P. VoCI, Diritto ereditario romano, II, Milano 1963, s. 102; M. BORKOWSKA, op. cit., s. 71; J. BARDACH, Statuty litewskie a prawo rzymskie, cit., s. 156 i n.

${ }^{44}$ Por. P. DĄBKOWSKI, Prawo prywatne polskie, II, cit., s. 87. 
Porównajmy następnie powyższy przepis statutowy z następującym fragmentem Instytucji.

I. 2,10,6: Testes autem adhiberi possunt ii, cum quibus testamenti factio est. sed neque mulier neque impubes neque servus neque mutus neque surdus neque furiosus nec cui bonis interdictum est nec is, quem leges iubent improbum intestabilemque esse, possunt in numero testium adhiberi ${ }^{45}$.

Wydaje się, że już pierwsze zdanie przytoczonego fragmentu Instytucji wykazuje zgodność z rozpatrywanym przepisem statutowym. Tekst rzymski mówi co prawda ogólnie o testamenti factio, a więc zdolności testamentowej natomiast ustawa litewska traktuje konkretnie o składniku wymienionej zdolności w postaci zdolności do sporządzania testamentu (testamenti factio activa), ale zbieżność stanowisk obu rozpatrywanych prawodawstw jest $\mathrm{w}$ omawianym punkcie łatwo uchwytna. Także następny element wyliczony przez ustawodawcę rzymskiego zgodny jest $\mathrm{z}$ enumeracją zawartą w przepisie statutowym. W obu ustawodawstwach do kategorii testes nie zaliczano kobiet. Prawo statutowe, podążając za wzorem źródła rzymskiego, zachowało tu nawet kolejność wyszczególniania, wymieniając kobiety na drugim miejscu ${ }^{46}$. Kontynuując analizę wskazanego tekstu justyniańskich Instytucji należałoby następnie stwierdzić różnicę między prawem rzymskim a litewskim. Obserwujemy bowiem, że źródło rzymskie wymienia dalej inne osoby niezdolne do objęcia funkcji świadka testamentowego, a wśród nich niedojrzałych, niewolników, niemych, głuchych, chorych psychicznie oraz

\footnotetext{
${ }^{45}$ Por. też Ulp. 20, 7: Mutus surdus furiosus pupillus femina neque familiae emptor esse neque testis libripensve fieri potest. Ulp. 20,13: Mutus surdus furiosus itemque prodigus, cui lege bonis interdictum est, testamentum facere non possunt: mutus, quoniam verba nuncupationis loqui non potest: surdus, quoniam verba familiae emptoris exaudire non potest: furiosus, quoniam mentem non habet, ut testari de sua re possit: prodigus, quoniam commercio illi interdictum est et ob id familiam mancipare non potest.
}

${ }^{46}$ Por. P. DĄBKowski, Prawo prywatne polskie, I, cit., s. 209. 
tych, którym zabroniono rozporządzać majątkiem i wreszcie odsądzonych od czci. Brak tego wyliczenia we fragmencie statutowym. Jest to jednak - jak się wydaje - różnica pozorna bowiem kategorie osób wskazane tak drobiazgowo przez Instytucje mieszczą się w zasadzie w grupie osób, które według I Statutu nie mają w ogóle prawa czynienia testamentów ${ }^{47}$, a zatem - w myśl artykułu szesnastego $\mathrm{z}$ rozdziału piątego litewskiej kodyfikacji - także prawa do występowania jako świadkowie przy ich sporządzaniu. Dotyczy to właśnie dzieci, niewolników, wydanych w cudzą moc oraz chorych umysłowo. Jedyną więc jak dotąd różnicę między uregulowaniami rzymskimi i litewskimi w rozpatrywanym punkcie stanowią niemi, głusi oraz pozbawieni możliwości rozporządzania majątkiem, których wymieniają Instytucje, a o których milczy Statut. Następnie jednak I Statut oddala się od stanowiska zajmowanego przez prawo rzymskie. Kodyfikacja litewska decyduje bowiem, że świadkami czynności sporządzenia testamentów nie mogą być ekzetutorowe abo opekunowe togo $\dot{z}$ tastamentu, co nie znajduje już odpowiednika w prawie rzymskim ${ }^{48}$.

W dalszej kolejności I Statut wymienia tych, kotorym $w$ tom tastamente szto otpisano, a więc zapisobiorców ${ }^{49}$. W tym przypadku prawo litewskie zajęło już przeciwne w stosunku do prawa rzymskiego stanowisko. $\mathrm{O}$ ile bowiem prawo justyniańskie nie zezwalało spadkobiercy na występowanie w roli świadka przy czynności sporządzania testamentu, $z$ mocy którego dziedziczy ${ }^{50}$, to jednocześnie bez przeszkód dopuszczano do rzeczonej funkcji legatariuszy i fideikomisariuszy.

I. 2,10,11: Legatariis autem et fideicommissariis, quia non iuris successores sunt, et aliis personis eis coniunctis testimonium

${ }^{47}$ Por. Statut I, V, 14.

${ }^{48}$ Por. też Statut I, V, 9 oraz P. DĄBKowski, Prawo prywatne polskie, II, cit., s. 95 i n.

${ }^{49} \mathrm{O}$ zapisach na wypadek śmierci por. Statut I, V, 12; V, 15; Statut II, VII, 7; Statut III, VII, 4.

${ }^{50}$ Por. I. 2,10,10. Inaczej G. 2,108. 
non denegamus, immo in quadam nostra constitutione et hoc specialiter concessimus, et multo magis his, qui in eorum potestate sunt, vel qui eos habent in potestate, huiusmodi licentiam damus $^{\text {st }}$.

Legatariuszy zaś - jak wynika z wyżej cytowanego przepisu statutowego - wykluczało prawo litewskie.

Krótka analiza przepisów statutowych odnoszących się do świadków testamentowych prowadzi do wniosku, że także w tej kwestii oddziaływanie prawa rzymskiego na litewskie zaznaczyło się już w I Statucie i znalazło swoją kontynuację w Statucie II i III.

W rozważaniach nad wpływem prawa rzymskiego na prawo spadkowe I Statutu litewskiego nie sposób pominąć artykułu zatytułowanego Chto by otca abo matku wdarit, czim majet karan byti.

Statut I, IV, 13: Też ustawljajem: jestli by syn wdarit abo zsoromotit, abo kotoryje wtiski abo perenagabanje jemu wczinit, togdy otec możet ot takowogo syna wsju jego otcziznu otdaliti. A jestli by otec syna ot otczizny otdalit, a inszych synow w sebe ne met, togdy imenja dwe czasti ne majet obczim ni otdaliti ani prodati, lecz tolko tyje dwe czasti majut prijti na bliznich, a tretjuju czast mo$\dot{z}$ et, gde chotja, tam obernuti. A i matka pod tym że obyczajem: jestli by syn abo dewka matku zsoromotili, togdy tak że matka możet otdaliti ot swojeje czasti ot materistogo. A wedżo tastamentom ne majet otec i matka syna i, doczki ot otczizny otdaliti, lecz, priszodczi pered nami, gospodarem, abo pered wradnikom, powedeti $i$ dati ne nego stusznyje pricziny, toż majet za jego wystup ztyj zapisom ot imenja otdalitit ${ }^{52}$.

${ }^{51}$ Por. R. TAUBENSChlaG, op. cit., s. 31; J. BARDACH, Statuty litewskie a prawo rzymskie, cit., s. 148 i n.

${ }^{52}$ Por. też Statut II, VIII, 7; Statut III, VIII, 7. 
Podany wyżej przepis statutowy porównajmy następnie z tekstem justyniańskiej Noweli 115 pochodzącej z 542 r. $^{53}$

Nov. 115, cap. 3: ... Causas autem iustas ingratitudinis has esse decernimus: Si quis parentibus suis manus intulerit. Si gravem et inhonestam iniuriam eis ingesserit ...

Wśród przyczyn wydziedziczenia Nowela wymienia na pierwszym miejscu uderzenie, a następnie ciężką krzywdę zadaną rodzicom przez dziecko. To samo czynił I Statut (jestli by syn wdarit abo zsoromotit, abo kotoryje wtiski abo perenagabanje jemu wczinit). Między powyższymi tekstami zachodzi więc daleko idąca zbieżność.

Analizując powyższy przepis Franciszek Bossowski stwierdzał, że I Statut w obliczu potrzeb, które ujawniały stosunki rodzime, recypował dwie pierwsze przyczyny wydziedziczenia podane przez Nowelę $115 \mathrm{w}$ postaci uderzenia lub znieważenia rodzica, ale zmienił ich funkcję tak, że stały się one przyczynami wyrzeczenia się dzieci przez rodziców, a nie powodami exheredatio. Bossowski wysunął przypuszczenie, że postanowienia Noweli przeszły do litewskiej kodyfikacji za pośrednictwem pomników prawa bizantyjskiego Eklogi i Procheironu, które stanowiły istotną część materiału prawnego zawartego w ruskich Kormczych Knigach. Bezpośrednim wzorem dla rozpatrywanego unormowania statutowego miałaby być bizantyjska instytucja apokerixis, polegająca na wyrzeczeniu się dziecka przez ojca i zasadniczo różniąca się od exheredatio, która jednak po przeszczepieniu na grunt litewski zbliżyła się bardzo do instytucji wydziedziczenia ${ }^{54}$. Zdaniem

${ }^{53}$ Nowela podawała m.in. powody wydziedziczenia dzieci przez rodziców w czternastu punktach (cap. 3), natomiast rodziców przez dzieci w ośmiu punktach (cap. 4), które jednak częściowo odpowiadały co do treści owym czternastu. Por. P. VocI, Diritto ereditario romano, II, cit., s. 668 i n.; W. LITEWSKI, s.v. Exheredatio, [w:] Stownik encyklopedyczny, cit., s. 92 i n.; A. SoKoŁowsKA, Dziedziczenie beztestamentowe wedtug Nowel Justyniańskich, Warszawa 2000, s. 43 i n. (maszynopis pracy magisterskiej); W. WoŁODKIEWICZ - M. ZABŁOCKA, op. cit., s. 180, 186.

${ }^{5.1}$ Por. F. BossowsKI, Nowela Justyniana 115 - Statut Litewski I R. IV. Art. 13 (14), Statut Litewski II i III R. VIII. Art. 7. - T. X. Cz. 1 Art. 167, [w:] Księga pamiqtkowa, cit., s. 107 i n. 
Bossowskiego instytucja wydziedziczenia w postaci znanej ze Statutu II, a także ze Statutu III, ukształtowana została już bezpośrednio pod wpływem prawa justyniańskiego ${ }^{55}$.

Kodyfikacje litewskie z lat 1566 i 1588 zawierały bardziej niż I Statut rozbudowane przepisy, które w sposób pogłębiony przedstawiały problematykę wydziedziczeñ ${ }^{56}$. Już dość pobieżna analiza wspomnianych norm skłania do akceptacji spostrzeżeń Bossowskiego o zależności tych przepisów wprost od Corpus Iuris Civilis i prowokuje do nowych dociekań. Okoliczności te nie powinny jednak przysłaniać faktu, że początki oddziaływania prawa rzymskiego na omawiane regulacje statutowe wiązać należy z kodyfikacją $\mathrm{z}$ roku 1529.

Powyższe obserwacje skłaniają do zrewidowania poglądu wyrażonego niegdyś przez Taubenschlaga, że: „Przeważna część ustępów, których zależność od prawa rzymsko-bizantyńskiego dało się wykazać, znajdują się li tylko w drugiej redakcji Statutu. Wskazuje to, że statut ten dopiero w tej redakcji i to więcej w swej łacińskiej wersji niż w ruskiej - możliwe pod wpływem Rojziusa - uległ pewnemu zromanizowaniu"s7. Taubenschlag w konkluzji swego wartościowe-

${ }^{55}$ Por. F. Bossowski, op. cit., s. 114 i n. Wnioski wyprowadzone przez F. Bossowskiego zwracają uwagę na ważny aspekt problematyki związanej z wpływami prawa rzymskiego na Statuty litewskie. Wskazują one bowiem na możliwość oddziaływania tego prawa dwoma kanałami - przez prawo bizantyjskie za pośrednictwem prawa ruskiego (zagadnienie to nie jest dotąd zbadane) oraz bezpośrednio poprzez Corpus Iuris Civilis. Istotnym czynnikiem przenikania prawa rzymsko-bizantyjskiego na Litwę musiał być również fakt stosowania Nomokanonu przez sądy kościelne w Wielkim Księstwie. Praktykę tę potwierdzały przywileje monarsze. Por. I. DANIŁOWICZ, op. cit., s. 266 i n.; J. BARDACH, Statuty litewskie a prawo rzymskie, cit., s. 25. Aspekty, o których mowa są - jak się wydaje - szczególnie istotne i aktualne w dociekaniach nad wpływem prawa rzymskiego na I Statut.

${ }^{56}$ Por. Statut II, VIII, 7 oraz Statut III, VIII, 7. Por. też A. MickIEwICZ, op. cit., s. 148 i n.; F. MORZE, op. cit., s. 116 i n.; I. DANIŁOWICZ, op. cit., s. 262 i n.; P. DABKOWsḰI, Prawo prywatne polskie, I, cit., s. 115, 158; TENŻE, Prawo prywatne polskie, II, cit., s. 46 i n., 77; R. TAUBENSCHLAG, op. cit., s. 32 i n.

${ }^{57}$ Por. R. TAUbenschlag, op. cit., s. 36. 
go, aczkolwiek cząstkowego tylko szkicu, popełnił - jak się wydaje dwa podstawowe błędy. Pierwszy stanowiła zbyt pochopna - bo podjęta bez równoległej analizy odnośnych przepisów I Statutu ocena, że częściowej romanizacji uległ dopiero Statut z 1566 r. Drugim błędem było poszukiwanie wpływów romanistycznych jedynie w łacińskim i polskim tekście II Statutu ${ }^{58}$, a nie w jego ruskiej wersji, która jako oryginalna, winna mieć dla badacza tej problematyki pierwszorzędne znaczenie i stanowić punkt wyjścia do dociekań w tym kierunku. Mankamentem pracy Taubenschlaga było ponadto powstrzymanie się od próby określenia zakresu wpływów romanistycznych w III Statucie. Badacz nie podjął więc próby uchwycenia dynamiki i charakteru przemian pierwiastków romanistycznych w poszczególnych Statutach ${ }^{59}$. Z przedstawionych porównań tekstów litewskich i źródeł rzymskich wynika, że w tego rodzaju analizach warto uwzględniać również przepisy I Statutu litewskiego.

\section{ROMAN ELEMENTS IN TESTAMENTARY REgULATIONS OF I LITHUANIAN STATUTE}

\section{Summary}

Roman law, alongside Lithuanian, Ruthenian, Polish, German and canon law, was one of the many sources of I Lithuanian Statute of 1529.

\footnotetext{
${ }^{58} \mathrm{R}$. Taubenschlag omyłkowo brał polskie tłumaczenie II Statutu za jego ruską wersję. Tekstu oryginalnego badacz ten nie znał. Por. R. TAUBENSCHLAG, op. cit., s. 6, $10,14,17,24,27$, gdzie autor nazywa cytowany tekst polski ruskim. Por. też J. BARDACH, Statuty litewskie a prawo rzymskie, cit., s. 120. J. Bardach uzupełnił zestawienie dokonane przez R. Taubenschlaga o oryginalny tekst ruski. Uczony ten ponadto słusznie przykłada duże znaczenie do analizy „wzajemnego stosunku wszystkich trzech tekstów II Statutu - ruskiego, łacińskiego i polskiego”, tamże, s. 53.

${ }^{59} \mathrm{Z}$ wymienionych powodów słusznie czynił R. Taubenschlagowi zarzuty J. BARDACH, Statuty litewskie a prawo rzymskie, cit., s. 24 i n., 52 i n. Bardach postulował równocześnie podjęcie prac szczegółowych nad romanizacją Statutów, trafnie oceniając, że zwłaszcza badania nad wpływem prawa rzymskiego na I Statut zostały zaledwie podjęte.
} 
However, it is still not clear how and within what scope the authors of the Lithuanian codification used Roman law. At some point researchers of the subject held the view that the reception of elements of elaborate Roman law could not have possibly happened before II Statute of 1566, from witch such elements were transferred to III Statute of 1588. It seems, however, that a number of Roman elements were already present in I Statute; later on, in the course of the creation of II and III Statute, Roman elements were considerably multiplied and expanded. An interesting subject for research in this connection is testamentary law in I Lithuanian Statute. For instance, Roman law did not allow for wills to be drawn up by minors, slaves, heretics, sons who remained under the authority of their fathers, and by insane persons. The same regulations are to be found in I Statute. It should be emphasized that the reception of Roman legal institution by the Lithuanian codification went as far as to include even exceptions to the general rules; thus, sons were allowed to make wills with respect to their separate property, and insane persons were allowed to make wills when they were in a sound state of mind. I Statute also adopted the Roman legal principle that allowed a testator to freely change his will at any moment in his life. An impact of the Roman legal system can also be seen in I Statute regulations concerning the capacity to be a witness to will making. Under I Statute, persons lacking will-making capacity and women could not be witnesses to will making. It also appears that disinheritance as a legal sanction for hitting or insulting one of the parents was taken over by I Statute from Roman law, perhaps via Byzantine law.

An analysis of the regulations of I Statute leads one to the conclusion that the first codification was already under the influence of Roman law, and that the influence was more significant that previously believed. In view of the above observations, further research on the issue may lead to interesting results. 